\title{
Effect of Calcium Salts on Allium cepa Chromosomes
}

\author{
M. P. Misra \\ Post-Graduate Department of Botany, Magadh University, \\ Bodh-Gaya, Bihar, India
}

Received December 15, 1979

Interesting results have been obtained by exposing chromosomes to various chemicals and physical factors (Bose 1967, Darlington 1947, Herich 1969, Kihlman 1966, Manna 1976, Mehra 1974, Moutschen 1978, Pantulu 1967, Raghuvanshi 1978 and Verma 1978). Some workers have tried to evaluate the effect of deficiency of certain elements on chromosomes (Das 1976).

The role of $\mathrm{Ca}^{++}$was clearly indicated in relation to chromosome structure by Cohn (1969) and Ambrose (1973).

The present work was taken up to see the effect of calcium salts namely $\mathrm{Ca}$ $\left(\mathrm{No}_{3}\right)_{2} 4 \mathrm{H}_{2} \mathrm{O}$ and $\mathrm{CaCl}_{2}$ on chromosomes. As calcium is one of the binding blocks of the nucleoprotein, it must have some relationship with the chromosomal activities in the cell.

\section{Materials and methods}

Ten healthy bulbs of Allium cepa were germinated in distilled water. Six bulbs with a good number of healthy roots were selected. Five bulbs were kept over specimen tubes filled with $0.021 \mathrm{M}, 0.042 \mathrm{M}, 0.063 \mathrm{M}, 0.084 \mathrm{M}$ and $0.105 \mathrm{M} \mathrm{Ca}$ $\left(\mathrm{No}_{3}\right)_{2} 4 \mathrm{H}_{2} \mathrm{O}$ salt solutions. The sixth bulb was allowed to grow in distilled water filled in a specimen tube. This served as a control for the experiment.

Two root tips were cut out every 24 hrs from each bulb. Root tips were washed in distilled water, fixed in 1:3 acetoalcohol, stained and squashed as usual. This process was repeated every $24 \mathrm{hrs}$ for $120 \mathrm{hrs}$. Chromosomal studies were made from temporary preparations. Photographs were taken to show features of interest.

The recovery of the cells could not be studied as the roots decayed after $120 \mathrm{hrs}$ in all the treated bulbs.

The cells were studied from five different fields of focus under the microscope. The number of cells affected were counted (without putting emphasis on the stages of division of the cells) and the total number of cells under the same focus was also counted. The percentage of cells affected were then deduced.

\section{Observations}

It was noted that only after $24 \mathrm{hrs}$ of treatment cells were affected. Higher concentrations $(0.084 \mathrm{M}$ and $0.105 \mathrm{M}$ ) produced $\mathrm{C}$-mitosis, chromosome breakage, stickiness within $24 \mathrm{hrs}$ of treatment. In some cases degeneration of chromatin started. The lower concentration showed the same effect but in lesser number of 
cells. After longer duration of treatment all cells were affected. The higher concentration treatment arrested the growth of roots only after $72 \mathrm{hrs}$ of treatment. There was complete degeneration of chromatin material in the cells after $120 \mathrm{hrs}$ of treatment.

Control showed normal behaviour of chromosomes upto $200 \mathrm{hrs}$. After that stickiness developed in the chromosomes.

The peripheral cells showed the effect of the chemicals first and after laps of more
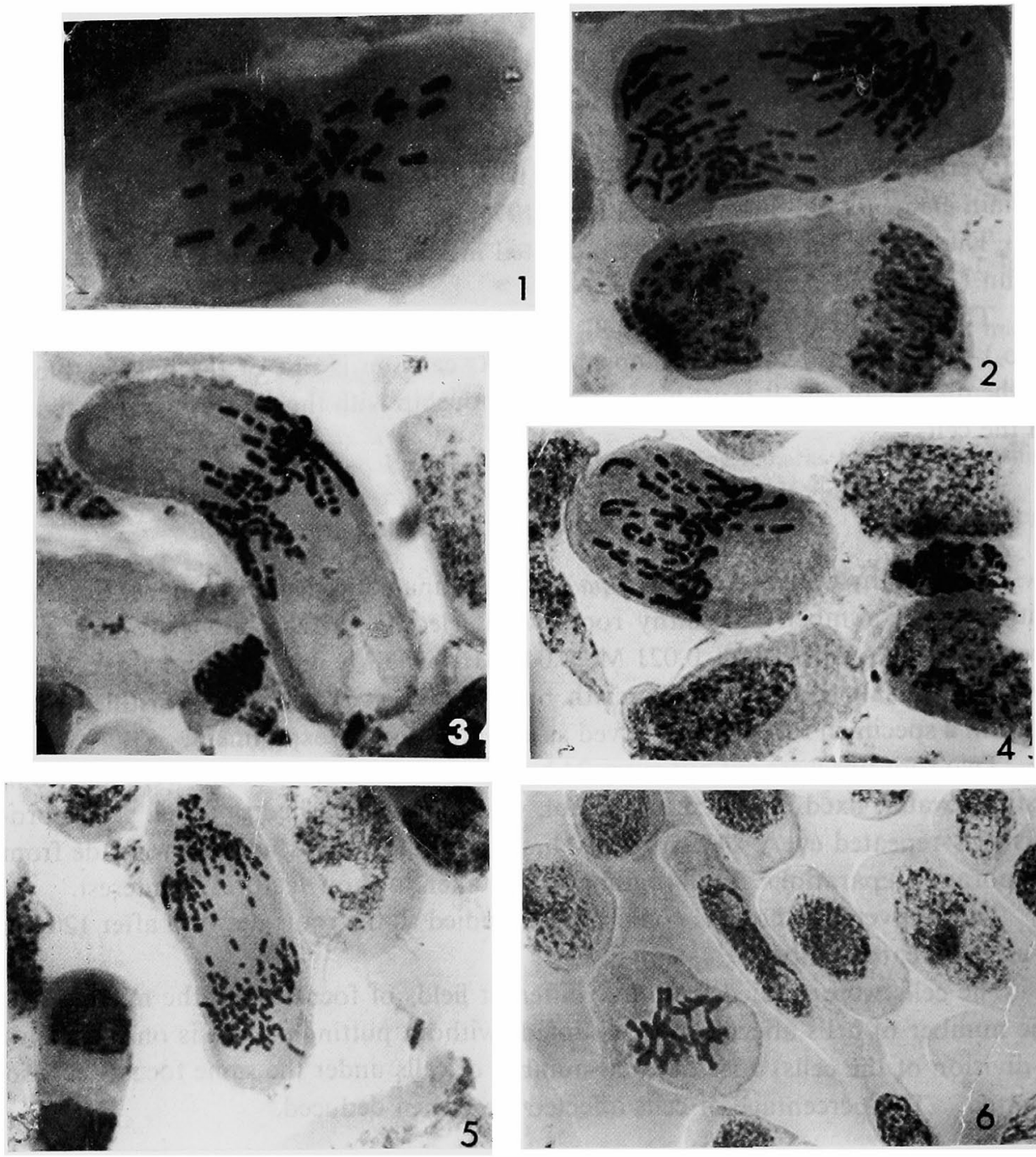

Figs. 1-6. Effect of $\mathrm{Ca}\left(\mathrm{NO}_{3}\right)_{2} 4 \mathrm{H}_{2} \mathrm{O}$ solutions on Allium cepa roots. 1-2: Effect of $0.021 \mathrm{M}$ solution after $24 \mathrm{hrs}$ of treatment. 1, higher number of chromosomes at its breakages at metaphase. 2 , higher number of chromosomes and its fragments at anaphase and late anaphase. 3, effect of $0.042 \mathrm{M}$ solution after $24 \mathrm{hrs}$ of treatment. Fragmented chromosomes at metaphase. 4-5: Effect of $0.063 \mathrm{M}$ solution after $24 \mathrm{hrs}$ of treatment. 4, fragmented chromosomes at metaphase. 5, fragmented chromosomes at anaphase. 6: Effect of $0.084 \mathrm{M}$ solution after $24 \mathrm{hrs}$ of treatment. 6 , stickiness in chromosomes at metaphase. 
time, more and more inner cells were affected. The degeneration of nuclei started after $96 \mathrm{hrs}$ to $120 \mathrm{hrs}$ in case of lower concentrations while in higher concentrations only after $72 \mathrm{hrs}$ of treatment.

Table 1. $\mathrm{Ca}\left(\mathrm{No}_{3}\right)_{2} 4 \mathrm{H}_{2} \mathrm{O}$ M. solutions showing $\%$ of cells affected after every $24 \mathrm{hrs}$ of treatment

\begin{tabular}{ccccccc}
\hline Time hrs & $0.021 \mathrm{M}$ & $0.042 \mathrm{M}$ & $0.063 \mathrm{M}$ & $0.084 \mathrm{M}$ & $0.105 \mathrm{M}$ & $\begin{array}{c}\text { Nature of } \\
\text { effect }\end{array}$ \\
\hline 24 & 10 & 15 & 25 & 35 & 45 & See photo- \\
48 & 25 & 40 & 55 & 60 & 75 & graphs \\
72 & 45 & 65 & 75 & 80 & 100 & \\
96 & 75 & 90 & 95 & 100 & 100 & \\
120 & 100 & 100 & 100 & 100 & 100 & \\
\hline
\end{tabular}
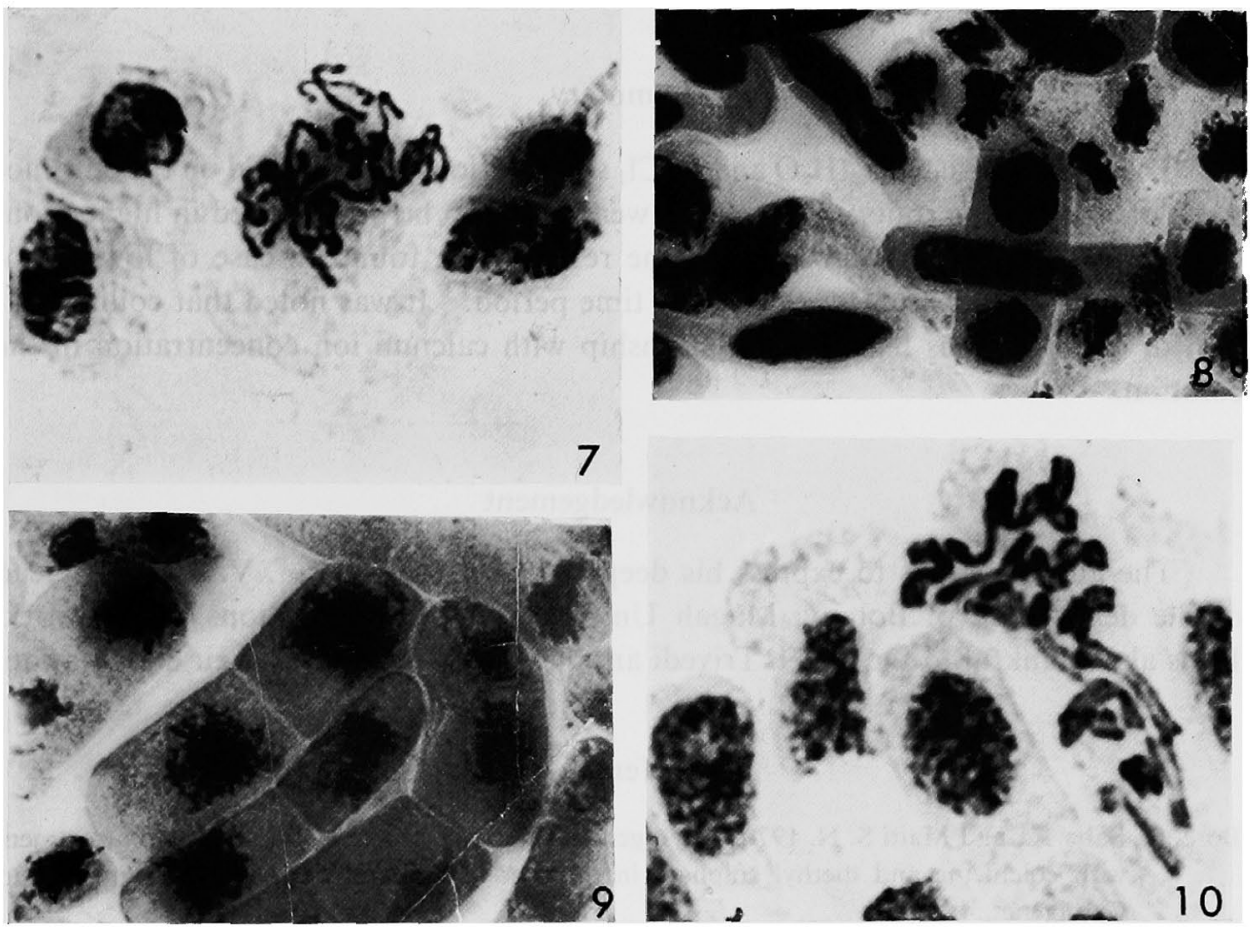

Figs. 7-8. 7, delayed coiling of chromosomes. 8-9: effect of $0.105 \mathrm{M}$ solution. 8, degeneration of nuclei after $24 \mathrm{hrs}$ of treatment. 9, all the nuclei showing degeneration after $120 \mathrm{hrs}$ of treatment. 10: Control in distilled water after $288 \mathrm{hrs}$. 10, normal metaphase plate.

A separate series of experiment was run with the same molar strength of $\mathrm{CaCl}_{2}$ salt solution. The results were visibly the same. As such no separate table and photographs were necessary.

\section{Discussion}

The result obtained clearly indicated that calcium ions played important roles 
in bringing about chromosomal breakage (by affecting the phosphate bridge) stickiness, C-mitosis, fragmentation, degeneration of chromatin material and complete elimination of nuclei from the cells (Sharma and Sharma 1972, Sharma 1976).

The structure of chromosome is basically dependant on the $\mathrm{Ca}^{+}$, and thus any change in the concentration of $\mathrm{Ca}^{+}$ions in the solution results in the imbalance of the nucleoprotein complex, leading towards a number of abnormal changes in the chromosomes.

The reduction in the size of the chromosome was partly due to elimination of heterochromatin portions and partly due to strain caused on account of tighter coiling of the nucleoprotein complex in the presence of higher ion concentration of $\mathrm{Ca}$ salt. In some of the cells stickiness and uncoiled chromosomes were noted at metaphase as if the higher concentration affected the coiling pattern adversely after the optimum concentration was reached.

\section{Summary}

The effect of $\mathrm{Ca}\left(\mathrm{No}_{3}\right)_{2} 4 \mathrm{H}_{2} \mathrm{O}$ and $\mathrm{CaCl}_{2}$ salt solutions were studied on the chromosome of Allium cepa roots. The effects were found to be pronounced in higher concentrations even after $24 \mathrm{hrs}$. The same results were found in case of lower concentrations but only after longer laps of time period. It was noted that coiling pattern of chromosomes had some relationship with calcium ion concentration in the solution.

\section{Acknowledgement}

The author wishes to express his deep indebtedness to Prof. V. Thakur, Head of the department of Botany, Magah University for his suggestions in this work. He is also thankful to Dr. R. N. Trivedi and Dr. B. K. Prasad for their cooperation.

\section{Reference}

Bose, S., Saha A., and Maiti S. N. 1970. Cytogenetic effects of pre and post-irradiation treatment with colchicine and diethyl sulphate in tomato. Studies in the $\mathbf{M}_{2}$ generation. Jour. Cytolgenet. 4: 44-55.

Cohn, N. S. 1969. Elements of Cytology, Harcourt, Brace and World Inc. U. S. A.

Darlington, C. D. and Koller P. C. 1947. The chemical breakage of chromosome. Heredity 1: 187.

Das, B. K. and Sen, S. P. 1976. The effect of deficiency of N, P, and K, on wheat and rice chromosome. Nucleus 19: 163-167.

Herich, R. 1969. The effect of zinc on the structure of chromosomes and on mitosis. Nucleus 12. 81-85.

Kihlman, B. A. 1966. In Action of Chemicals on Dividing Cells. Prentice Hall Inc. New Jersey, U. S. A.

Manna, G. K., Das, R. K. and Das, P. K. 1976. Chromosome aberrations in mice treated with maleic hydrazide, uracil and guanine. Nucleus 19: 40-46.

Mountschen, J. and Degraene, N. 1978. Berberine: a new tool in chromosome studies. Nucleus 43: $1-3$. 
Mehra, P. N. and Mann, S. K. Cytological effects of chemical mutagens on Pterotheca falconeri. Nucleus 17: $167-182$.

Pantulu, J. V. 1967. Chromosomal alteration in pearl millet induced by gamma-rays. Nature 213.

Raghuvanshi, S. S., Pathak, C. S. and Singh, A. K. 1978. Effects of pre-irradiated colchicine treatment on mutation spectrum of Phaseolus aurens Roxb. Cytologia 43: 143-151.

Sharma, A. K. and Sharma, A. 1972. Chromosome Technique. Butterworths London.

Sharma, A. 1976. The Chromosomes. Oxford and IBH Publishing Co. 66, Janpath, New Delhi.

Verma, A. K. and Sinha, B. M. B. 1978. Chromosome pairing in X-irradiated Pteris longifolia L. Cytologia 43: 181-185. 